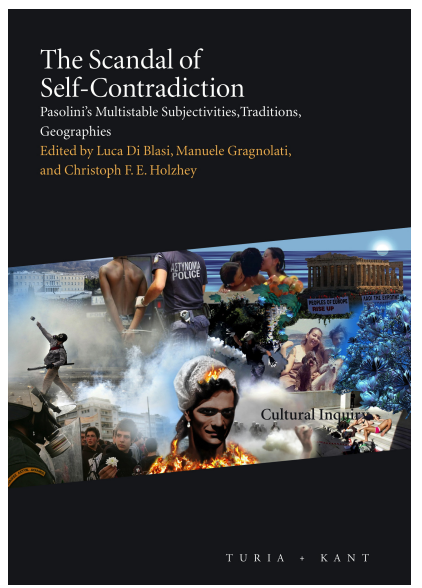

The Scandal of Self-Contradiction: Pasolini's Multistable Subjectivities, Geographies, Traditions, ed. by Luca Di Blasi, Manuele Gragnolati, and Christoph F. E. Holzhey, Cultural Inquiry, 6 (Vienna: Turia + Kant, 2012), pp. 237-54

PREVIOUSLY PUBLISHED AS:

| Identical except for DOI prefix 10.25620

\section{HERVÉ JOUBERT-LAURENCIN}

\section{Figura lacrima}

\author{
CITE AS:
}

\begin{abstract}
Hervé Joubert-Laurencin, 'Figura lacrima', in The Scandal of SelfContradiction: Pasolini's Multistable Subjectivities, Geographies, Traditions, ed. by Luca Di Blasi, Manuele Gragnolati, and Christoph F. E. Holzhey, Cultural Inquiry, 6 (Vienna: Turia + Kant, 2012), pp. 23754 <https://doi.org/10.37050/ci-06_13>
\end{abstract}

\section{RIGHTS STATEMENT:}

(C) by the author(s)

This version is licensed under a Creative Commons AttributionShareAlike 4.0 International License.

ABSTRACT: Talking about tears in Pasolini's cinema evokes the brief moment in Mamma Roma, when a boy hums Una furtiva lagrima in a mocking tone as he sits on a staircase. The man's tear doesn't even try to pass for real; it is, in short, a pure 'tear of the cinema', made of glycerin, but it assumes, as such, in the story, a figurative reality integrated in the 'real' within the fiction and the character's psychology. 


\section{FIGURA LACRIMA}

Hervé Joubert-Laurencin

The popular songs in Pasolini's oeuvre - notwithstanding their apparent lightheartedness and even because of it - always carry a greater meaning than anticipated. And the fact that he wrote several songs for Laura Betti when she was a professional singer and translated into Italian the very beautiful songs of Manos Hadjidakis in Dušan Makavejev's film Sweet Movie (1974) confirms his interest in songs. The heartbreaking song Fenesta ca lucive, which he included in his anthology of dialectic poetry, is heard thrice in his films, starting with Accattone (1961), where it is whistled by one of the Neapolitans when the prostitute Maddalena undergoes a nighttime beating; this song is heard again in $\mathrm{Il}$ Decameron (The Decameron, 1971) where it is sung by Franco Citti and his Neapolitan hosts who have settled in Germany and again in I racconti di Canterbury (The Canterbury Tales, 1972) where it is sung with a strong English accent. The Duke in Salò (1975) hums Quel motivetto che mi piace tanto and changes the ' $d u d u d u d u d u d u$ ' into 'dada dada dada', Dada being the alternate title the filmmaker initially envisaged for Salò.

Talking about tears in Pasolini's cinema evokes the brief moment in Mamma Roma (which incidentally is the story of a son who, in pawning a record, sells his mother's memories and the song of her life: Violino tzigano), when a boy hums Una furtiva lagrima in a mocking tone as he sits on a staircase. At this moment in the story, the young man makes fun of the crocodile tears of Carmine, Mamma Roma's expimp who comes to ask her to go back to work for him; the re-appearance of Accattone in Carmine thanks to the actor Franco Citti - whose face is horizontally intersected by a thin, fake mustache, on which he wipes a vertical tear - is 'to cry for'; and the high-heeled shoe that Anna Magnani angrily throws at the mocking boy ends in a close-up on the screen, thus echoing, via this visual quotation, the sequence of the beating of the other prostitute in Accattone - in other words, it colours this moment with a feeling tinged with both violence and injustice. The 'furtive' tear changes its meaning: in Donizetti's 1832 opera L'elisir d'amore (The Love Potion) from which it is taken, it is a proof of love (not so 
furtive), but in Mamma Roma, it signifies a purely conventional, sentimental blackmail (not furtive at all). The man's tear doesn't even try to pass for real; it is, in short, a pure 'tear of the cinema', made of glycerin, ${ }^{1}$ but it assumes, as such, in the story, a figurative reality integrated in the 'real' within the fiction and the character's psychology, which says a lot about feelings and the place of what is real and what is not in Pasolini's cinema.

It's no accident that the tear runs on Franco Citti's face. But a popular pastiche of the well-known L'elisir d'amore brings us to another film to be investigated. I am referring to Bobby Solo's song Una lacrima sul viso, which became a hit in Italy the year of the shoot and of the release of Il Vangelo secondo Matteo (The Gospel According to Matthew). In the last week of February 1964, during the famous Festival di San Remo, Bobby Solo had his prize withdrawn because he violated the competition rules, singing his maudlin romance about a new feminine tear that would be a proof of love in playback. (The silent mimicry of the lips and of the gestures of love synchronized with a pre-recorded sound, this separation of voice and body, must have been considered by the San Remo jury, supreme arbiter of Italian song, as the equivalent of a glycerin tear). In the same year, between 24 April and the end of July, Pasolini shot his Gospel. That a tear was important in Pasolini's story of Christ just after 1964 San Remo allows me to put my inquiry under Bobby Solo's tutelary, kitsch shadow.

My study is divided into two parts. The first is devoted to the LACRIMA and the second to the FIGURA. I will employ two methods that, although not dominant practice in the humanities, provide convincing results: film analysis for 'lacrima' and the interpretation of an 'untranslatable' for 'figura'.

The history of film analysis began in earnest in the 1970s. It arose, as a method of research, with the dual appearance of home VCRs (which made films widely available) and academic film studies. I first discovered Jesus's little tear in Pasolini's Gospel while teaching: a student suddenly saw it because, the week before, I had analyzed both the tear cited from Dante's Purgatorio in the film Accatone: a phrase from the Divine Comedy appears in black and white on a title card) and the hero's filmed but hidden tear, which is present, but barely visible, like many lacrimette, or 'small' tears of cinema, in the dream sequence of the funeral and not at the end of the film, as we would expect after 
Dante's phrase that opens the film. Since then, I have noticed the presence of a great number of tears in Pasolini's films whose qualitative importance is equally recognized in the particular economy of each work.

Translation, on the other hand, is a much older practice than film analysis, and the 'problem of translation' is obviously as old as translation itself. An important French dictionary, Vocabulaire européen de philosophie, carries the subtitle Dictionnaire des intraduisibles (Dictionary of Untranslatables) because its first, constitutive gesture, as Barbara Cassin, its main editor explains, was to gather the explanatory footnotes of translators of philosophy whenever they encountered a more or less insurmountable problem of translation. ${ }^{2}$ As a translator myself of diverse works of Pasolini's into French, I noticed that the recurring expression 'integrazione figurale', without being literally untranslatable, necessitates complex and varied translations, depending on its numerous occurrences in the filmmaker's theoretical work.

\section{1. $L A C R I M A$}

If, as I have just mentioned, Accattone, Pasolini's first film, opens with a quote about a tear, this means that we must take this piece of information into account; in so doing, we would probably not be contradicted by a literary analysis of Pasolini's relationship to the elegiac: his entire cinema is born of a tear.

The last shot of the credits, which is also the first narrative image of the film, isn't an image - not a modern image, a view neither of Rome nor of a man, it is a written and Dantesque tear: 'Per una lacrimetta che'l mi toglie' (Purgatorio, V, 107). It refers to the figure of Bonconte da Montefeltro, a great sinner who was saved by a lone tear of repentance running down his cheek at the moment of his death. There is no doubt that the first and final meaning of this surprising and enigmatic opening is of the greatest importance for understanding Pasolini's relationship to his Western heritage, with which this volume is also concerned - namely, the relationship between the living and the dead, as I will try to show in the conclusion of this first part. Nevertheless, among the dozens of tears in Pasolini's oeuvre (and it is worth emphasizing that there is not one of his films where somebody is not crying), I will first of all consider Christ's little tear in 1964 as central. Then, in 
the purely virtual hypothesis of a long, uninterrupted film made up of all Pasolini's films put together, I will consider the tear-function operating in Accattone (1961) as a flash-back and that in the Decameron as a flash-forward.

My first analysis of Christ's tear took place in my 1995 monograph on Pasolini: ${ }^{3}$ relying on Maurizio Viano's research, ${ }^{4}$ I noted that there is only a single passage, made up of twelve shots, that cannot be considered as taken from one of the verses of the Gospel of Matthew, but is instead, deliberately invented (in terms of its place, action, and choice of characters, but not in terms of the dialogue, since the scene is silent). It is a question of a meeting - or a pseudo-meeting - of Christ with his mother, an elderly Mary, played by the filmmaker's own mother, Susanna Pasolini. Christ is accompanied by his apostles and walks on a path framed by low, drystone walls. To the right of the group of the walking men, a house is visible in the distance (the alert viewer recognizes the general shape of Mary's home in Bethlehem; if the viewer has a very good memory - or undertakes a detailed analysis of the film - he or she can even recognize the setting from one of the film's first shots, which combines in a shot/reverse shot a young Mary wordlessly explaining to her husband Joseph that, despite not having consummated her marriage with him, she is pregnant through the workings of the Holy Spirit); there follows a shot of the walking men, already in the distance, on the stony path; a close-up shows Christ turning his face towards the right of the frame, and a tear rolls down his cheek for the extremely attentive viewer; his elderly mother moves forward on a terrace that overhangs the plain where the men of faith pass; full of sorrow, she looks leftwards in the frame.

In the standard grammar of classic film editing - which the film largely obeys - this series of shots is a false continuity of distance. The relationship between the two spaces - that of the road and that of the house - is first established by the alternation of shots of the walkers and of the house, then an insurmountable distance is signified by the shot of men in the distance on the road. If one wanted to make known that Christ unequivocally exchanged a glance with his mother, their two glances should have preceded this shot of estrangement. Despite the real distance in the filmed landscape, the conventional logic of classical editing would have sutured without difficulty, in the filmic space, the two glances exchanged in the viewer's mind; it would have sufficed to place the two shots of glances before the others, rather than after, in order to 

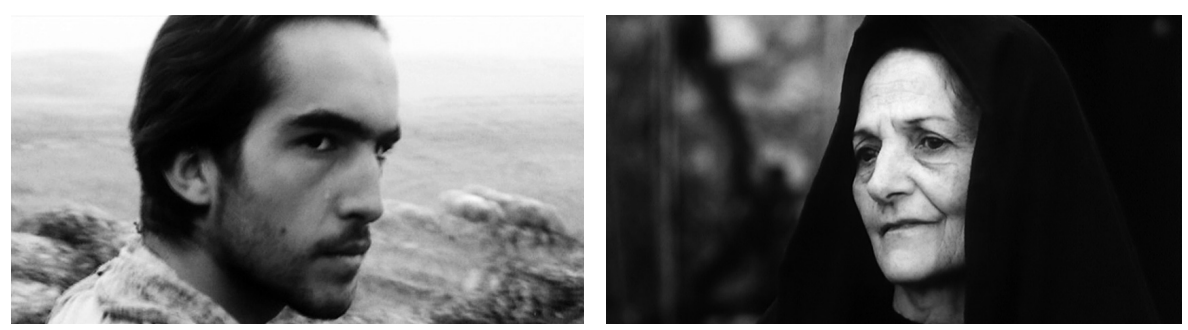

Fig. 1. Il Vangelo secondo Matteo, 1964: exchange of gazes between Christ and his mother.

notice it. This is a 'false' continuity because it doesn't altogether prevent the viewer from thinking that he or she was able to see an impossible shot/reverse shot or a little magic between two characters standing at a great distance from each other. In other words, in seeing this brief passage, masterfully edited, we cannot decide if Christ intimately communicated with his mother and let her know that he wept either at the thought of losing her or of not passing some time with her as a good son, or if their two glances remained blind, turned toward a filmic black hole (Fig. 1). One of the recurrent pieces of music heard in the film is the sorrowful Negro spiritual 'Sometimes I Feel Like a Motherless Child', and this sequence of the non-encounter (or of the 'non-reconciliation'5) immediately follows one where Christ publicly 'rejects' his family, and particularly, through the editing, his mother who has come to meet him, by explaining that his apostles constitute his only family.

More than that, the false continuity produces an event in the very act of looking and casts doubt on it. It erases the sight in three ways: deleting it, marking it, and rendering it hyper-sensitive. Pasolini's invention of placing a tear in a false continuity makes him one of the great inventors of forms in the history of film editing. Carmine, before the Roman Mother incarnate ('Mamma Roma'), didn't believe in his own 'furtive' tear: what about that of a Christ, whose apocryphal character is compensated for only by the disjunction of a false continuity?

In short, it is impossible to know in the Gospel According to Matthew what is happening and what is said, in this pure intensity that is, in a way, the Pasolinian centre of the film and of Christ's story: a moment that Lacan would have called real (as an impossible, heartbreaking moment 'that limps') between Mother and Son, except that, against all logic and the natural order of life, the Son will die before the one who gave birth to him. 
A close analysis of the film, instead of relying on the spectator's memory, allows us to delve deeper and to notice the work of exact parallelism between, on the one hand, this supernumerary sequence of false continuity between Jesus-Pasolini as enunciator and the elderly MarySusanna, the filmmaker's mother, and, on the other, the film's masterly opening in which the young Mary is repudiated by her husband Joseph (played by Marcello Morante, Elsa's brother). This debut, completely silent and based on glances and constructed in the editing, is one of the most beautiful moments in all of the filmmaker's oeuvre. This reinforces the problematic of tradition since the initial sequence fits into the film's mode of representation in the wake of three basic, Christological models: the virginal conception (in its opposition to the dogma of the Immaculate Conception), the Annunciation, and the Incarnation.

\section{VIRGINAL CONCEPTION}

On a first, very simple level, the clear parallelism between the two sequences amounts to putting the son in the father's place via a profane comparison, not to say a profanation. Indeed, if the Holy Spirit, as well as the Father and the Son, is completely present in the opening sequence, the structural logic that its shot-by-shot similarity establishes with that of the non-encounter in no way constructs a representation of the Trinitarian dogma.

If Joseph is a visible Father and the Son an invisible third who directs the scene, ${ }^{6}$ the Holy Spirit, it could be said, lies 'in the splice, ${ }^{7}$ between the close-up of Mary's eyes (third shot of the film) - which modestly lower their gaze (the actress Margherita Caruso gently closes her eyelids, and then lowers her head) - and the shot of her that follows in the editing (shot number five), a medium shot that makes visible, by a link shot in the axis, her rounded belly: Joseph learns, with the spectator, by sight, that his wife is pregnant, as if she became so from one shot to another. The virginal birth and the beginning of Western civilization's New Testament is thus a matter of editing. Insofar as the sequence of the non-encounter imitates the opening sequence of the film, Christ's gaze - seemingly both wrathful and contrite - and the tear on his filial countenance looks more like a repetition of a family drama, that of Mary's betrayal and Joseph's silent repudiation of her: 
Matthew I, 18: Now the birth of Jesus Christ was as follows: when His mother Mary had been betrothed to Joseph, before they came together she was found to be with child by the Holy Spirit.

I, I9: And Joseph her husband, being a righteous man and not wanting to disgrace her, planned to send her away secretly.

Specifically, the virginal conception of Jesus returns to a mythical construction present in older, diverse religions, as is always the case with the religious theme in Pasolini, which totally conflicts with the belated dogma - in the Marian reinterpretation made official in the nineteenth century - of the Immaculate Conception that claims Mary was exempt at birth from the original sin dispensed to the rest of humanity and that has the effect of removing all sexual innuendo (the enigma of the unconsummated marriage) and all conjugal scandal in the mystery (the primitive sequence of the silent repudiation). The Pasolinian Virgin is particularly virgin and immaculate, but, like the primitive divine virgins, through the scandal of the sex. The editing speaks clearly.

As does the composition of the image - the oxymoron of the virginal conception seems to me directly represented, in Pasolini's film, by the medium shot of Mary pregnant, contained exactly in the frame of a stone archway whose interior has been filled and where nevertheless the absence of some stones in the upper right lets in daylight: hymen both closed and open.

\section{ANNUNCIATION}

The second Pasolinian appropriation constructed by the sole structuration of sequences concerns the choice of representing, on the screen, the Annunciation made to Joseph (made to a man) in place of the most famous posture in Italian painting: the Annunciation made to Mary. In fact, the film, as narrative, makes the choice of opening with a demonstrative ellipsis of the Annunciation, since it begins with those sublime, frontal shots of Margherita Caruso - a delicate and stubborn young girl with a Mona Lisa smile showing her big belly to Elsa Morante's brother who, as her husband, is more overwhelmed than indignant. (Of course, Pasolini here clearly follows the Gospel of Matthew, where there is no evocation of the Annunciation episode, but the filmmaker has chosen this Gospel rather than another and he hasn't kept all its episodes.)

Beyond the passage from feminine to masculine, the parallelism between the film's beginning and the sequence of the Lacryma Christi ${ }^{8}$ 
complements a greater and more mysterious identity between father and son. Joseph, disappointed by the sight of his wife's belly, leaves home and sets off towards Bethlehem taking a familiar path, framed by the low, drystone walls: the same path that much later in the film and in history the apostles will take with the adult Jesus. He approaches the city (represented by a village in the region of Basilicata), and his neck enters into the fore of the frame, a completely recognizable, visionary effect. The Lord's angel has revealed to him the truth - which he happily believes - as his smile indicates:

Matthew I, 20: But when he had considered this, behold, an angel of the Lord appeared to him in a dream, saying, 'Joseph, son of David, do not be afraid to take Mary as your wife; for the Child who has been conceived in her is of the Holy Spirit.

I, 2I: She will bear a Son; and you shall call His name Jesus, for $\mathrm{He}$ will save His people from their sins'.

Returning home, Joseph finds Mary and they smile at each other, still without a word, signaling their mutual understanding. The shot/reverse shot thus conveys a reconciliation (the out-of-focus gravel behind Joseph, similar in its figurative effect to the black background on which Mary also stands out) contrasting with the initial separating encounter that opens the film (a sharp background for Mary, as opposed to the blurry one for Joseph, which was filmed with another lens). ${ }^{9}$

Immediately after the sequence of the Lacryma Christi, Christ is shown leaving on the same road, framed in the same manner as his father when he was demoralized by his wife's presumed betrayal. $\mathrm{He}$ also appears before Bethlehem with his neck entering into the foreground. But unlike his father, he will not return home and instead embarks upon the Passion, walking towards death, as if he were continuing an episode from the life of his father, but limited to its single, sorrowful aspect.

\section{INCARNATION}

Is it possible to find in some of Pasolini's filmic constructions - as certain analysts of French film suggest, following in the footsteps of Daniel Arasse's and Georges Didi-Huberman's descriptions of paintings of the Annunciation - the equivalent of an impossible 'representability'? For Teresa Faucon, the beginning of Pasolini's Gospel According to Matthew paradoxically 'replays the space of the Annunciation', ${ }^{10}$ even 
though, following to the letter the Gospel of Matthew, there is a precise ellipsis: Alain Bergala, writing about Accattone, puts wings on Stella analyzing the sequence in which she meets Accattone for the first time. ${ }^{11}$ In both cases, it is the Virgin herself who becomes the archangel Gabriel. The reference to the Annunciation, as important as it is in Italian painting, doesn't strike me as essential for evoking the Incarnation. Faucon's and Bergala's analyses - which pinpoint small discrepancies between beings, minimal intervals that form nonetheless real contrasts of worlds (which can be summed up by the opposition between the 'sacred' and the 'profane') - remain exact, but perhaps they should be limited, as their authors themselves suggest, to the problematic of the Incarnation. Even if the Virgin Mary and Accattone's girlfriend do not partake of the divine, they can be considered as 'sacralized', as Pasolini rightly suggests, and thus as partaking of another space than that of the characters around them, which necessitates a particular representation that sometimes finds solutions in primitive or Baroque painting (traditionally, Pasolini passes over the Quattrocento) and sometimes invents specifically filmic solutions.

FLASH-FORWARD

In The Decameron, Franco Citti, the principal incarnation of Pasolini's films - the ex-Accattone who, in a dream, bewails his death and dies without a tear; the ex-Carmine of Mamma Roma crying his crocodile tear - becomes Ciapelletto, who accumulates every sin, including murder and pederasty; he is the first enunciator and the common thread of the multiple stories drawn from Boccaccio before being replaced in this function, in the middle of the film, after his brutal death and his tears, by the painter Giotto, played by Pasolini himself. Ciapelletto is sent by his master to the regions in the North to find the Neapolitan clients - in short, mafiosi cousins in Germany. He feasts with them and together they sing Fenesta ca lucive. One of the Neapolitans makes a gesture with his finger mimicking the tear on the cheek of the song's unhappy heroine, confined by her family, removed from her lover who calls for her at her window ('The window that sparkled sparkles no more'); she died of a broken heart: 'Chiagneva sempe ca durmiva sola. Mò dorme cui morti accumpagna-aaata' ('She cried all day because she slept alone. Now she sleeps together with the dead'). During the meal, Ciapelletto suffers an attack, and his head falls heavily on the table, just as in the sequence in Accattone where the protagonist gets drunk or pretends to 
get drunk (the viewer will never know which it is) with the Neapolitan pimps. The ambiguity of the little tear then makes its mark, although handled satirically, because Ciapelletto bewails his minor sins before the city's holiest and most naive confessor, played by Pasolini's painter friend, Giuseppe Zigaina, who, himself, cries loudly about it. Ciapelletto, the mafioso bandit, will be buried and revered like a saint: here again, we'll never know if the power of the redemption of purgatorial thinking is to be taken seriously or mocked.

FLASH-BACK

Likewise, the question of the Dantesque lacrimetta and the 'Purgatory version', which is not without influence on the possible meaning of Christ's 1964 tear, was evident in the first film. On this point, I am going to limit myself to a reference to my 1995 analysis ${ }^{12}$ and to summarizing Giorgio Passerone's contradictory and fascinating reading from 2006, with the goal of reuniting these lachrymose scenes, which, despite their apparent differences, are really very similar.

The beginning and the end of the film: when Accattone, chased by the police for a minor crime, dies as the result of a motorcycle accident, he utters the following words: 'Mò sto bene' ('Now, I feel good'), but no tear appears on his face, even though his redemption was programmed by the initial quotation from Dante that recalls Bonconte da Montefeltro, saved by his final tear of repentance.

Nevertheless, in analyzing the film, I noticed earlier therein a tear running down his face as he dreams about his own burial: the idea of Redemption - of the third term between Salvation and everlasting Damnation - is thus present despite everything; Pasolini comments on this sequence by evoking his character's religious simplicity, his 'atavistic Catholicism impregnated with a pagan superstition [...], his weak and confused act of redemption'. ${ }^{13}$ It's worth adding that Pasolini refers several times in his writings to the adventure of another Montefeltro, Guido (told in Inferno, XXVII, 19-23), father of the Bonconte of the final tear. I maintain that Pasolini presents an Accattone dogmatic in his naive dream and personally extricates himself from him by denying him the expected salvation at the end. I believe that Pasolini is here close to the proceedings of the logician devil who sent Guido da Montefeltro to Hell 'because contradiction is not permitted': you cannot sin and buy your salvation; there must be repentance. In other words: crying is necessary. Giorgio Passerone is right to criticize me for opposing an anti- 


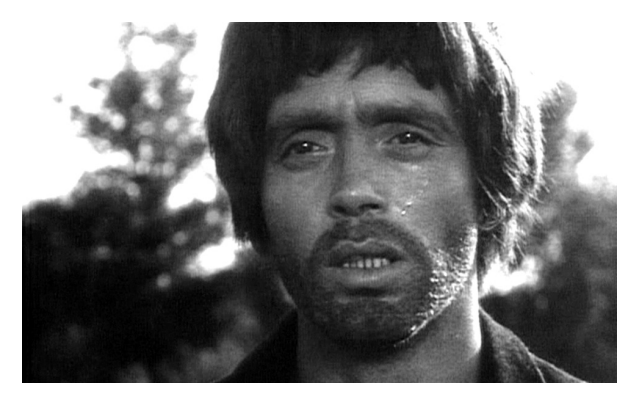

Fig. 2. Edipo re, 1967: a new tear on Franco Citti's face.

dogmatic Pasolini to Dante, when Dante is no more dogmatic than he. At the end of some dense and beautiful pages, Passerone writes: the invented showing (montrage) [...] makes [the viewer] experience "the "little tear" of a vital death, that of all the South excluded from our present'. ${ }^{14}$ This means that Giorgio Passerone, despite the objective assertions offered by an analysis of the film, claims, with a very reasonable hyperbole, that the (so to speak) musical meaning of the Divine Comedy doesn't allow for a recognition of the absence of the little tear at the end (because the film itself, you might say, weeps), nor a recognition of its presence in Accattone's dream that would make of the character a religious man in the dogmatic sense (undoubtedly in the sense that Accattone, beyond his narrative adventure, remains an abnormal character; he is himself both a 'South excluded' and a 'vital death'). We could therefore say that in Accattone, we see and we don't see a man who doesn't weep and a tear of religious, dogmatic repentance. I am completely in agreement with this way of thinking and I don't think I said otherwise in my 1995 essay that Giorgio masterfully discusses. All that, of course, concerns Accattone but is also essential to the understanding of Christ's tear, and thus to the comprehension of Pasolini's cultural heritage. ${ }^{15}$

So when we clearly see a tear - real or not - roll down the cheek of Enrique Irazoqui, Pasolini's Spanish Christ, we are right to remember a tear from a popular song, like those that Pasolini included in and occasionally even created for his films (i.e. the memory of Bobby Solo) and to appreciate, in his spectator's pure heart, the melodrama without irony of a son who cries for having been too hard on his mother and 'sometimes feels like an orphan' (Fig. 2). ${ }^{16}$ 
But we can also consider that the tear opens up a post-theological mystery, a secularized Messianic question: for whom does this new Christ weep? For which world does He cry? To collect what heritage, from which West?

\section{FIGURA}

In Western civilization, Christ crying is a common visual and literary trope. Traditionally, the 'Man of Sorrows' cries for humankind and the world. On the other hand, to make a connection between the Christ of the New Testament with the 'little tear' of Purgatory as Pasolini in fact does and as is revealed only by a comparative analysis of several of his films - in other words, to make a link between Christ's Passion and that of the weighing of the sinner's soul - is heretical. As always, heresy attacks orthodoxy in its central point: here, the dual nature of the Son of Man, both divine and human, a kind of Kippbild or bistable figure. ${ }^{17}$ The little tear, because it is transferred to God's face (il Volto di Dio), mixes past and present, sacred and profane, heritage and heirs. ${ }^{18}$

Pasolini's specific and heretical conceptualization of the 'figure', of the figura or more precisely of the 'figural integration', allows us to grasp the tensional inner workings of his thinking.

'Figural integration' (integrazione figurale) is a strange, old-fashioned expression that Pasolini often uses in his criticism when he empirically but surely aspires to a theorization. Despite the similarity of the words, it doesn't tally - without however being completely separate with the 'figural interpretation' that refers, in Erich Auerbach, Pasolini's favorite philologist, to the medieval, theological conception of 'figurism', an evolved form of 'typology'.

Typological or hermeneutic exegesis is a Christian interpretation of the Old Testament that finds therein foreshadowings (characters, events, and institutions) of the New Testament. For example, in his 'Epistle to the Romans', Saint Paul characterizes Adam as a type of Christ, Christ becoming the antitype, and the Jews of the Sinai period are presented as Christian types. This conception obeys the idea of repetition. Figurism - although close or seemingly close - doesn't exactly match the same principles. This interpretation sees in the Old Testament figures and predictions that are fulfilled or will be fulfilled not in the time described by the Evangelists, but in the era of Salvation. The con- 
firmation no longer obeys the principle of cyclical repetition, but the idea of fulfillment, a linear or even better a vertical principle. The major theme of real prophecy has a very pronounced ideological dimension: Paul above all reinforces Christianity's authority and tries to universalize it in rereading, term for term, the elements of Mosaic Law (i.e., the Jewish Law of Moses) according to the Christian Promise (the word and the life of Jesus); his conversion opens the biblical corpus to a larger world. ${ }^{19}$

Thus, Pasolini's greatest script, which never made it to the screen, Saint Paul (1966-1974), begins with the following warning: 'The poetical idea of this film (that should also become both its main theme and its novelty) consists of transposing the entire life of Saint Paul to a contemporary context', ${ }^{20}$ endeavouring from its first to last line to enact a transposition of the transposition, since Pasolini makes of the New Testament story of Paul's journeys the 'Old' and makes of the modern world of the 1960s the new 'New', by reinventing a neo-figurism that is deeply secular and political.

Pasolini employs the expression 'integrazione figurale', from its very first usage, as if it were a common, shared idea: 'The figural integration - to adopt a term of stylistic criticism [...]'; 'Stylistic critics say that every work possesses its "figural integration". ${ }^{21}$ Auerbach could certainly be one of these 'stylistic critics' - at least for Pasolini, who read him in Italian - inasmuch as the phrase 'integrazione figurale' appears once in the Italian version of Mimesis as the translation of the concept of 'fulfillment' ('Erfüllung', 'Figurale der Erfüllung'), ${ }^{22}$ already present in the Latin expression 'figuram implere' quoted by Auerbach. ${ }^{23}$ However, attributing the phrase 'figural integration' to Auerbach alone would seem to me somewhat inappropriate. Pasolini's usage probably constitutes a technical expression of his literary stylistics ante 1956 (date of the first occurrence I have located) and is no exact equivalent of figurism - a concept which is not stylistic but theological and which Auerbach finds throughout Dante and in a large part of medieval literature. Although Pasolini, who is generally not stinting in his references to Auerbach, never cites him when he employs the expression 'figural integration', a conceptual common ground seems obvious on several occasions. It is difficult to say whether this parallel originates in a controlled deviance of Pasolini's thought or if it is an amateur's simple approximation. But Pasolini is always slightly ahead of us. 
On this point, we cannot settle for Walter Siti's explanation; in his very first preface to Pasolini's oeuvre in Meridiani, ${ }^{24}$ he evokes an allpurpose concept, a 'crowbar' serving to force the already open doors, but Siti's needlessly polemical description makes him miss the secondary plurality, like the first citational normality, of Pasolinian uses of the term. Nor can we follow Silvia De Laude in her intelligent inventory of Pasolini's citations of Auerbach, because she believes that the exact expression 'figural integration' occurs in Auerbach, without however proving it.

To date, I have made an inventory of fourteen direct uses of the expression 'figural integration' in Pasolini's sayings and writings between 1956 and 1971. Indirectly, the use in the sense close to 'integrare', 'integrante', 'integrazione', 'integra', and 'inintegrabile' adds another eight instances, pushing its use as late as 1974 when, in an interview, Pasolini - then in the middle of shooting Salò - concludes that he will continue to create as long as he is convinced that a part of his work remains 'inintegrabile' ('unrecoverable' or 'non negotiable') by society.

Interpreting an 'untranslatable' makes you see the importance of the expression, the complexity and polysemic richness of its usages.

The use of 'figural integration' in an article written in Vie Nuove during the 'Tambroni summer' - politically hopeless but the summer of Accattone's gestation - marks the beginning of a specific use of the concept. ${ }^{25}$ It becomes an avatar of the 'trigger mechanism' ('clic' in Italian) à la Leo Spitzer, ${ }^{26}$ a sound imprint, the pathos of a violent death, a detail that refers to a totality.

In 1970 Pasolini published an article entitled 'The Historical Sense' that refers more directly to the principle of figurism where the temporality of the work of art is at stake (here a historical film): 'The past becomes a metaphor of the present, in a complex relationship, because the present is the figural integration of the past. ${ }^{27}$ Finally, the use in the celebrated text that theorizes a screenplay as both a literary and non-literary form ${ }^{28}$ takes us into the cinema-literature relationship and above all into the cinema-life relationship, the very principle of the paradoxical transcendence of figurism. Pasolini's concept is thus more and more remote from the Auerbach of Figura or Mimesis, but perhaps not so distant from the young Auerbach who drew inspiration from a text by Walter Benjamin. The temporal dimension brings together the Pasolinian conceptual invention with Walter Benjamin's 'Jetzt der Lesbarkeit', 
namely the idea that every work of art possesses its 'moment of legibility', both inscribed in it from the beginning and revealing itself only through the contact with the gazes that welcome it in its history, without this relation's ever confining itself to a single 'reception'. ${ }^{29}$

Thus, henceforth lacrima can be understood as figura. With the song furtiva lacrima in Mamma Roma, we understand now that the Carmine type represents the return of the Accattone antitype, and that this 'poem of return' is understood as a kind of figurism of film casting. We understand now that Christ's little tear from 1964 not only plays a complex role in its relationship, shot by shot, to the opening sequence of the same film, but is understood by intertextuality with other films and other quotations from Dante, via a post-Auerbachian, heretical figurism. This figurism retrieves the theological power of the idea of a fulfillment in the order of salvation, or rather, from a secular viewpoint, of a verticality of time alone capable of justifying a 'Proustian' relationship between two moments 'horizontally' separated on the plane of chronology, in order to apply it to the real world of humans, which is de-theologized. Then art, representation, play, tears, cinema, can become, during an expanded moment, reality. And a revolutionary hope can be born: that of another world, not ideal but already here, in the past or in the future, which would be added temporarily, at least in a liberating promise, to the Western world of suffering and horror, imprisoned in a present without bifurcations.

For whom does this new, twentieth-century, Pasolinian Christ cry? For which world? The Brazilian filmmaker and critic Glauber Rocha responds, beginning with his first articles on Buñuel's and Pasolini's paradoxical Christology (articles written between 1962 and 1968) until his last film A Idade da Terra (The Age of the Earth, 1980), a serious dialogue with Pasolini after his death: Christ cried for the Third World, because he was a political Christ.

'Integrazione figurale': the revolution consists of living this integration, while art consists of figuring it.

Translated by Sally Shafto 


\section{NOTES}

1 Writing on Krzysztof Kieślowski and his use of tears - real or make-believe - on the faces of the individuals he films in his documentaries and fiction films, Slavoj Žižek, in Lacrimae rerum (Paris: Editions Amsterdam, 2005), recalls cinema's dual nature, as an art of both representing and recording human feelings.

2 Vocabulaire européen des philosophes: dictionnaire des intraduisibles, ed. by Barbara Cassin (Paris: Editions Robert \& Seuil, 2004).

3 Hervé Joubert-Laurencin, Pasolini: Portrait du poète en cinéaste (Paris: Éditions des Cahiers du Cinéma, 1995), pp 104-06.

4 Maurizio Viano, A Certain Realism: Making Use of Pasolini's Film Theory and Practice (Berkeley: University of California Press, 1993), pp. 331-33, fn. 11.

5 Pasolini considered Jean-Marie Straub and Danièle Huillet's 1965 film Not Reconciled (Nicht Versöhnt oder Es hilft nur Gewalt, wo Gewalt herrscht) 'an extraordinary film and a foundational act of modern cinema' (Review in Cinemasessanta 60 (1966)).

6 The child in his mother's belly can be a complete character in an apocryphal Gospel: see the meeting of Jesus, still a fetus in the maternal womb, with the future Saint John the Baptist himself in the belly of his mother Elizabeth. See Jacques de Voragine, 'Lxxvi: La nativité de Saint Jean-Baptiste (24 juin)', in La legende dorée, trans. by Teodor de Wyezewa (Paris: Seuil, 1998), p. 305.

7 'Gertrud passed into the splice' is a retort made by Jacques Rivette in a roundtable discussion on Carl Theodor Dreyer's homonymous film, published in Cahiers du cinéma, 210 (March 1969), pp. 32-33. Here is the quotation in full: 'From Vampyr to Ordet, Dreyer seizes and cuts into the three or four cuts-ellipses, in the splice of two shots each made up of a long duration that intervene calmly in the supposed continuity of the scene: deliberately disturbing and provocative scenes that cause the viewer to wonder where Gertrud has passed: she has passed into the splice.'

8 There is a pagan tradition of Christ's tear, but it seems only culinary. The altar wine is Christ's blood in the rite, but the Neapolitan wine called Lacryma Christi, cultivated on Vesuvius, is the desecration of another physical liquid of the Saviour.

9 Teresa Faucon, Penser et expérimenter le montage (Paris: Presses de la Sorbonne Nouvelle, 2009), pp. 30-32.

10 Ibid.

11 Alain Bergala, 'Montage obligatoire', in Le montage dans tous ses états, Conférences du Collège d'Histoire de l'Art Cinématographique, v (Paris: Cinémathèque Française, 1993), pp. 1-16 (pp. 7-8).

12 Joubert-Laurencin, Pier Paolo Pasolini, pp. 63-70.

13 Pier Paolo Pasolini, 'Il paradiso di Accattone', in Saggi sulla politica e la società, ed. by Walter Siti and Silvia De Laude (Milan: Mondadori, 1999), p. 943. First published as 'Accattone e Tommasino', Vie Nuove, 26, (1 July 1961), pp. 14146.

14 Giorgio Passerone, 'Eretica commedia (Pasolini ab-gioia)', in Passages pasolin- 
iens, ed. by Giorgio Passerone and René Schérer (Villeneuve d'Asq: Presses du Septentrion, 2006), pp. 193-306 (p. 252).

15 In this discussion, Giorgio Passerone and I overlooked several leads, including Pasolini's article 'I segni viventi e i poeti morti' (1967), in Empirismo eretico, in Saggi sulla letteratura e sull'arte, ed. by Walter Siti and Silvia De Laude, 2 vols (Milan: Mondadori, 1999), II, pp. 1573-81, which adds to this compendium of tears those of Manfred, who was killed on the Benevento bridge and whose body was intentionally abandoned, like Pasolini's, a lume spento (Purgatorio, III, 10345); the article rightly opens with an evocation of the epilogue from Oedipus Rex, where Franco Citti, again him, allows a tear to run down his left cheek before disappearing into the field.

16 In Les violons ont toujours raison (Paris: Presses Universitaires de France, 2000), Louis Skorecki maintains that 'in the cinema, we love only love stories' (p. 70).

17 At times Christ cries like a god (we see a rabbit whose ears are a gloriole), at others he cries like a man (we see a duck with only a beak) - if we want to relate this theological phenomenon to Joseph Jastrow's famous image of the duck-rabbit on which Wittgenstein and Gombrich commented. (Cf. also the introduction to this volume and Manuele Gragnolati's essay.)

18 The image of Christ, both human and divine, was recently (October 2011) the object of an enormous scandal in Paris: the play by my friend Romeo Castellucci, entitled Sul concetto di Volto nel Figlio di Dio, was violently attacked for a supposed 'christianophobia' by extremist Christian activists who invaded the Théâtre de la Ville and threw stink bombs and balls of waste oil onto the spectators before being evicted by the police. The back of the scene was wallpapered with the giant face of Christ painted by Antonella da Messina.

19 See Marc de Launay's postscript in Erich Auerbach, Figura, trans. by Diane de Meur (Paris: Macula, 2003), pp. 117-36.

20 Pier Paolo Pasolini, Per il cinema, ed. by Walter de Siti and Franco Zabagli, 2 vols (Milan: Mondadori, 2001), II, p. 2023: 'L'idea poetica - che dovrebbe diventare insieme il filo conduttore del film - e anche la sua novità - consiste nel trasporre l'intera vicenda di San Paolo ai nostri giorni.'

21 Pier Paolo Pasolini, 'Nota a Una polemica in versi', in Le ceneri di Gramsci, in Tutte le poesie, ed. by Walter Siti, 2 vols (Milan: Mondadori, 2003), I, p. 865: 'L'integrazione figurale - per adoperare un termine di critica stilistica [...]'. See also 'Il disco di Vie Nuove sull'eccidio di Reggio Emilia', in Saggi sulla politica e sulla società, p. 897: 'I critici stilistici dicono che ogni opera ha la sua "integrazione figurale"'.

22 Erich Auerbach, Mimesis. Il realismo nella letteratura occidentale, trans. by Alberto Romagnoli and Hans Hinterhäuser, 2 vols (Turin: Einaudi, 2000 [1956]), I, p. 128; cf. Mimesis. Dargestellte Wirklichkeit in der abendländischen Literatur (Tübingen: A. Francke Verlag, 2001 [1946]), p. 113.

23 Ibid., p. 83 (Italian) / p. 75 (German).

24 Walter Siti, 'Tracce scritte di un'opera vivente', preface to Pier Paolo Pasolini, Romanzi e racconti, ed. by Walter Siti and Silvia De Laude, 2 vols (Milan: Mondadori, 1998), I, p. lxxxi. 
25 Pasolini, 'Il disco di Vie Nuove', p. 897: 'I critici stilistici dicono che ogni opera ha la sua "integrazione figurale": ossia ogni opera, nell'atto di essere scritta o letta, brano per brano, pagina per pagina, parola per parola, si integra in una sua totalità immanente ad essa in una sua ideale conclusione che le dà continuamente senso e unità. Così per questo disco - è atroce dirlo - la integrazione figurale, che gli dà quasi una dignità estetica, è la morte dei giovani lavoratori di Reggio, è la calcolata brutalità della polizia: fatti che tutti noi sappiamo, e che quindi integrano in noi, con la loro disperata violenza e con la loro raggiunta coscienza, le tremende pre-grammaticalità del disco.'

26 See Leo Spitzer, Études de style, pref. by Jean Starobinski (Paris: Gallimard, 1970).

27 Pier Paolo Pasolini, 'Il sentimento della storia', in Saggi sulla letteratura e sull'arte, II, p. 2819: 'Infatti il passato diviene una metafora del presente: in un rapporto complesso, perché il presente è l'integrazione figurale del passato.'

28 Pier Paolo Pasolini, 'La sceneggiatura come "struttura che vuole essere altra struttura", in Empirismo eretico, in Saggi sulla letteratura e sull'arte, I, p. 1489: 'Il dato concreto del rapporto tra cinema e letteratura è la sceneggiatura. Non mi interessa però tanto osservare la funzione mediatrice della sceneggiatura, e l'elaborazione critica dell'opera letteraria che essa conduce, "integrandola figuralmente" con la prospettiva altrettanto critica dell'opera cinematografica che essa presuppone.'

29 See Erich Auerbach, 'Zur Dante-Feier', in Erich Auerbach: Geschichte und Aktualität eines europäischen Philologen, ed. by Karlheinz Barck and Martin Treml (Berlin: Kulturverlag, Kadmos, 2007), pp. 407-08. This early article by Auerbach directly refers to Walter Benjamin's 'Schicksal und Charakter', published in 1921 in the journal Die Argonauten, in Gesammelte Schriften, ed. by Rolf Tiedemann and Hermann Schweppenhauser, 7 vols (Frankfurt am Main: Suhrkamp, 1974-89), II/I (I977), pp. 171-79. The two essays are already close to the Pasolinian theme of death as 'editing of our life'. The idea that '[e]very now is the now of a determined knowability' (Jedes Jetzt ist das Jetzt einer bestimmten Erkennbarkeit), or of a 'legibility' (Lesbarkeit), is found in Walter Benjamin, Das Passagenwerk, in Gesammelte Schriften, v/1 (1982), p. 577-78. 


\section{REFERENCES}

Auerbach, Erich, Mimesis. Dargestellte Wirklichkeit in der abendländischen Literatur (Tübingen: A. Francke Verlag, 2001 [1946]). In Italian as Mimesis. Il realismo nella letteratura occidentale, trans. by Alberto Romagnoli and Hans Hinterhäuser, 2 vols (Turin: Einaudi, 2000 [1956])

— 'Zur Dante-Feier', in Erich Auerbach: Geschichte und Aktualität eines europäischen Philologen, ed. by Karlheinz Barck and Martin Treml (Berlin: Kulturverlag, Kadmos, 2007), pp. 407-08

Bergala, Alain, 'Montage obligatoire', in Le montage dans tous ses états, Conférences du Collège d'Histoire de l’Art Cinématographique, v (Paris: Cinémathèque Française, 1993), pp. $1-16$

Cassin, Barbara, Vocabulaire européen des philosophes: dictionnaire des intraduisibles (Paris: Editions Robert \& Seuil, 2004)

de Voragine, Jacques, 'LXXVI: La nativité de Saint Jean-Baptiste (24 juin)', in La legende dorée, trans. by Teodor de Wyezewa (Paris: Seuil, 1998)

Faucon, Teresa, Penser et expérimenter le montage (Paris: Presses de la Sorbonne Nouvelle, 2009)

Joubert-Laurencin, Hervé, Pasolini: Portrait du poète en cinéaste (Paris: Éditions des Cahiers du Cinéma, 1995)

Pasolini, Pier Paolo, Per il cinema, ed. by Walter Siti and Franco Zabagli, 2 vols (Milan: Mondadori, 2001)

_ Saggi sulla politica e sulla società, ed. by Walter Siti and Silvia De Laude, 2 vols (Milan: Mondadori, 1999)

Tutte le poesie, ed. by Walter Siti, 2 vols (Milan: Mondadori, 2003)

Passerone, Giorgio, 'Eretica commedia (Pasolini ab-gioia)', in Passages pasoliniens, ed. by Giorgio Passerone and René Schérer (Villeneuve d’Asq: Presses du Septentrion, 2006), pp. 193306

Siti, Walter, 'Tracce scritte di un'opera vivente', preface to Pier Paolo Pasolini, Romanzi e racconti, ed. by Walter Siti and Silvia De Laude, 2 vols (Milan: Mondadori, 1998), I, p. lxxxi

Skorecki, Louis, Les violons ont toujours raison (Paris: Presses Universitaires de France, 2000)

Spitzer, Leo, Études de style, pref. by Jean Starobinski, trans. by Éliane Kaufholz, Alain Coulon, and Michel Foucault (Paris: Gallimard, 1970)

Viano, Maurizio, A Certain Realism: Making Use of Pasolini's Film Theory and Practice (Berkeley: University of California Press, 1993)

Žižek, Slavoj, Lacrimae rerum (Paris: Editions Amsterdam, 2005) 